\title{
A missing piece: the spiny mouse and the puzzle of menstruating species
}

\author{
Nadia Bellofiore1,2, Fiona Cousins'1,2, Peter Temple-Smith², Hayley Dickinson ${ }^{1,2}$ and Jemma Evans ${ }^{3}$ \\ 'The Ritchie Centre, Hudson Institute of Medical Research, Clayton, Australia \\ 2Obstetrics and Gynaecology, Monash University, Clayton, Australia \\ ${ }^{3}$ Centre for Reproductive Health, Hudson Institute of Medical Research, Clayton, Australia \\ Correspondence should be addressed to J Evans: jemma.evans@hudson.org.au
}

\begin{abstract}
We recently discovered the first known menstruating rodent. With the exception of four bats and the elephant shrew, the common spiny mouse (Acomys cahirinus) is the only species outside the primate order to exhibit menses. There are few widely accepted theories on why menstruation developed as the preferred reproductive strategy of these select mammals, all of which reference the evolution of spontaneous decidualisation prior to menstrual shedding. Though menstruating species share several reproductive traits, there has been no identifiable feature unique to menstruating species. Such a feature might suggest why spontaneous decidualisation, and thus menstruation, evolved in these species. We propose that $a \geq 3$-fold increase in progesterone during the luteal phase of the reproductive cycle is a unique characteristic linking menstruating species. We discuss spontaneous decidualisation as a consequence of high progesterone, and the potential role of prolactin in screening for defective embryos in these species to aid in minimising implantation of abnormal embryos. We further explore the possible impact of nutrition in selecting species to undergo spontaneous decidualisation and subsequent menstruation. We summarise the current knowledge of menstruation, discuss current pre-clinical models of menstruation and how the spiny mouse may benefit advancing our understanding of this rare biological phenomenon.
\end{abstract}

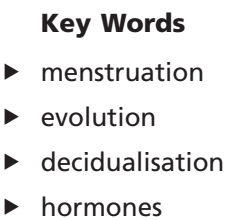

Journal of Molecular Endocrinology (2018) 61, R25-R41

\section{Introduction}

Menstruation occurs in a select number of mammals. The majority of menstruating species are higher order primates, including humans and Old World monkeys (Emera et al. 2012, O'Neil 2014, The International Union for Conservation of Nature and Natural Resources 2015); only the elephant shrew (Van der Horst \& Gillman 1941) and four species of bats (Rasweiler 1991, Rasweiler \& De Bonilla 1992, Zhang et al. 2007) have also been shown to menstruate. Evolutionary links between these menstruating species are ambiguous.
Shedding of the superficial layer of the endometrium (stratum functionalis) in the absence of embryonic implantation is the discerning feature separating menstruating and non-menstruating species. The limited number of menstruating species, particularly laboratory species, has restricted research into this poorly understood biological process. Specifically, knowledge of the underlying mechanisms of post-menstrual endometrial repair the development of pregnancy complications specific to menstruating species, and infertility of 
non-gonadal origin remain elusive (Salamonsen 2003, Brosens et al. 2009, Treloar et al. 2010).

We recently discovered the common or Egyptian spiny mouse (Acomys cahirinus), a rodent native to Africa and the Middle East, undergoes spontaneous decidualisation and subsequent menstruation, being the only known rodent to exhibit overt menses (Bellofiore et al. 2017). This discovery has the potential to supersede the current induced models of menses and aid in unmasking the mechanisms of menstrual associated disorders in women and provide a pre-clinical model for pharmacokinetic studies of drug targets for contraceptives.

This review will provide an update on what is currently known about the menstrual cycles of primate and nonprimate species, with an emphasis on the spiny mouse. It will also highlight the potential use of the spiny mouse as a translational model for menstruation and menstrual disorders and propose a new hypothesis to explain why menstruation may have evolved.

\section{Female mammalian reproductive cycles}

Around half the world's population are women; billions of women therefore undergo menstruation each month for approximately a third of their lives. As humans experience menses, it is a common assumption that cyclical endometrial shedding at the conclusion of an infertile cycle is widely experienced throughout the animal kingdom. However, menstruation as a cyclical physiological phenomenon is surprisingly rare, with the majority of female reproduction in mammals characterised by oestrous cycles.

Common to both oestrous and menstruating species are the physiological changes to the reproductive tract in preparation for mating and pregnancy, which occur in response to ovarian steroidal hormones. Oestradiol-17B is the key hormone during the follicular phase of the ovarian cycle (proliferative phase of the uterine cycle) leading up to ovulation, while progesterone is essential during the luteal phase of the ovarian cycle (secretory phase of the uterine cycle) when females are most receptive to embryo implantation.

During the follicular phase of menstrual/oestrous cycles, final maturation of a dominant ovarian follicle occurs. A substantial increase in oestrogen production triggers a pre-ovulatory surge in luteinising hormone (LH) and subsequent ovulation. In species with an oestrous cycle, these ovulatory triggers are variable and dictated by the environment. Oestrous mammals generally remain under-influenced by factors such as nutrition, temperature, rainfall and light. In the case of lightmediated reproductive regulation, the pineal gland and melatonin secretion are particularly important (Downey 1980). Hence, in most of the mammalian kingdom, mating is restricted to a specified breeding season and/or relies on induction from male pheromones or vagino-cervical stimulation from coitus, within a very discrete window of female receptivity (oestrus/'heat') during the late follicular phase. In contrast, menstruating species exhibit cyclical ovulation, irrespective of light, temperature or pheromonal cues, and spontaneously transition into their active luteal phase (Witherspoon 1971, Schams et al. 1977, Downey 1980).

Some mammalian species do not exhibit a luteal phase at all unless ovulation is first triggered. Cats, ferrets, squirrels and rabbits are all reflex ovulators; only ovulating after a surge in $\mathrm{LH}$ resulting from the mechanical stimulation by male genitalia. In these species, an excitatory threshold during coitus is required in order to stimulate pituitary LH production of sufficient levels to induce follicular rupture, followed by formation of a functional, progesterone-secreting corpus luteum to initiate a luteal phase (Downey 1980). Figure 1 summarises key differences between menstruating and oestrous species.

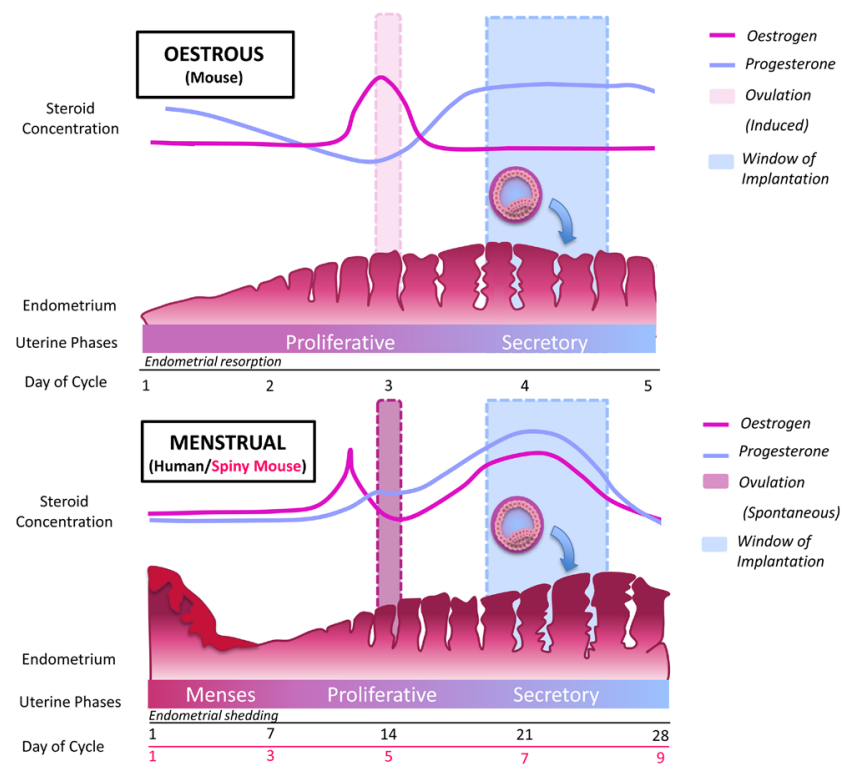

Figure 1

Comparative reproductive cycles of menstrual vs oestrous mammals. In oestrous species (e.g. wild mice), ovulation is triggered by seasonal cues, and a decline in progesterone leads to endometrial resorption. In menstruating species (e.g. the human and the captive spiny mouse), breeding is year-round and rapid withdrawal of progesterone leads to endometrial shedding i.e. menstruation. 
In the absence of pregnancy, luteolysis, functional degradation of the corpus luteum, is an active process in oestrous mammals that requires a complex endocrine interplay between the uterus and the ovary. Endometrial secretions of the luteolytic agent prostaglandin F2-alpha (PGF2A) are transferred from the uterine vein and to the ovarian artery. Here, PGF2A acts directly to induce the regression of the corpus luteum (McCracken et al. 1972, Auletta \& Flint 1988). In women and other menstruating species, however, this process is a primarily ovariandriven event (McCracken et al. 1999). The lack of a viable pregnancy and subsequent luteotrophic rescue signal from human chorionic gonadotrophin (hCG), results in the corpus luteum's inability to sustain progesterone production, which is followed by a cascade of endometrial events leading to menstruation and initiation of a new fertile cycle.

\section{Endocrine regulation of the luteal phase and spontaneous decidualisation in menstruating species}

In menstrual species, hormonal priming of the uterus prepares the endometrium for implantation, irrespective of the presence of a blastocyst. Dynamic changes to the endometrial stromal fibroblasts (ESFs) are stimulated through progesterone, regardless of exogenous signals from a developing embryo. Progesterone promotes the differentiation of ESFs into decidualised stromal cells (DSC); a terminal event in menstruating species (Brosens \& Gellersen 2006). While progesterone withdrawal by the regressing corpus luteum occurs in all oestrous mammals, causing regression of the endometrium, breakdown and shedding of the decidualised endometrium is only observed after regression of the corpus luteum and subsequent progesterone withdrawal in menstruating species (Brosens et al. 2009). DSC have a significant upregulation of progesterone receptors (PR) which, when activated, result in the production of anti-abortive factors such as progesterone-induced blocking factor and to signal recruitment of leukocytes in preparation for implantation (Druckmann \& Druckmann 2005). In the absence of successful embryo implantation, declining progesterone levels mediated by corpora lutea regression results in the withdrawal of luteal support from DSCs leading to an increase in production of inflammatory chemokines and cytokines known to mediate inflammatory leukocyte recruitment (Evans \& Salamonsen 2014). Inflammatory leukocytes perpetuate the inflammatory loop and release potent protease enzymes to initiate tissue breakdown (Salamonsen 2003). Endometrial stromal cells can no longer maintain haemostasis, resulting in focal bleeding and commitment to apoptotic pathways. In nonmenstruating species, which do not exhibit a spontaneous decidual response, and where endometrial stroma is therefore not terminally differentiated, the decline in progesterone results in endometrial resorption rather than shedding.

\section{Acomys cahirinus: the first known menstruating rodent}

The common spiny mouse (A. cahirinus) is a Middle Eastern rodent, already well established as unique in its physiology. Although not a common laboratory species, it has proved to be a useful animal model for biomedical research in diabetes mellitus and obesity - for which it has a notable susceptibility (Gonet et al. 1966, Strasser 1968), precocial fetal organ development (Oosterhuis et al. 1984), scar-free skin and hair follicle regeneration (Seifert et al. 2012) and non-human primate-like endocrinology (adrenal production of cortisol and dehydroepiandrosterone, which the common mouse and rat do not produce) (Lamers et al. 1986, van Weerden et al. 1992, Quinn et al. 2013).

We have confirmed the spiny mouse has a menstrual cycle ranging from 6 to 10 days (mean $8.7 \pm 0.4$ days) with a menstrual period lasting on average 3 days. This follows an active luteal phase with endometrial transformation of the stroma corresponding to a spontaneous decidual reaction. Although the spiny mouse menstrual cycle length is shorter than the 28-day cycle in women, the proportion of time spent menstruating accounts for $20-40 \%$ of total cycle length, which is relatively comparable to $15-35 \%$ seen in women (Bellofiore et al. 2017).

Our recent unexpected observation that the spiny mouse endometrium appears to demonstrate spontaneous decidualisation and subsequently menstruates, a feature of female reproduction that has never been reported in a rodent, is further evidence that suggests the unique place this species occupies in rodent phylogeny.

The evolution of menstruation remains a perplexing enigma, which is further complicated by this unexpected discovery of a novel non-primate species, which exhibits menstrual cycle qualities. The incidence of spontaneous decidualisation in the spiny mouse inarguably reiterates the necessity of this physiological process for resultant menstruation. 


\section{Evolution of specific reproductive traits in mammalian species: the critical role of decidualisation}

Mammalian systems of reproduction present an extraordinary array of evolutionary outcomes, particularly evident in pregnancy and birth. Gestation length spans from days (monotremes and marsupials) to months (humans) and even years (elephant); the mode of nutrient supply during in utero development varies from the oviparous monotremes hatched from leathery soft-shelled eggs to the placental, viviparous pouched metatherians in which milk acts as a 'post-birth' placenta (Guernsey et al. 2017) and placental eutherians. Using RNA sequencing on tissues at the feto-maternal interface, Lynch et al. (2015) identified uterine genes important in eutherian gestation and suggested that specific recruitment of genes rather than alterations in ancestrally expressed genes are essential for implantation and pregnancy phenotypes exhibited by menstruating species, specifically the recruited genes within DSCs. Many genes were recruited from neural systems, digestive systems and the haemolymphoid systems. They demonstrate that in menstrual species, genes recruited to the endometrium are significantly enriched for immune function, including leukocyte activation, uterine natural killer cell (uNK), T-cell and cytokine recruitment and cellular signalling. They also show a loss of endometrial ion transporters, which are known to play a crucial role in mineralisation of the egg-shell in birds, in favour of enhancement in metabolic processes. Finally, they established that recruited genes exhibit a higher degree of dynamic expression at different stages of the menstrual cycle, compared to ancestrally expressed genes. This pertains in particular to endometrial stromal cells, which are highly regulated through physiological reprogramming, elaborating the most extensive nonpregnant decidual phenotype. The regulation of recruited gene expression in the endometrium of menstruating species, particularly in regards to inflammatory genes, supports many theories that this reproductive strategy may indeed have evolved as an adaptive advantage, especially with respect to the inflammatory reaction in preparation for menstrual breakdown. However, there is no clear phylogenetic link connecting the relatively small number of diverse, menstruating species.

Species that undergo menstruation have evolved a combination of several important reproductive strategies (Table 1): cyclical ovulation, spontaneous decidualisation and extensive vascular remodelling of the endometrial stroma; aggressive trophoblast invasion; a haemochorial placenta, production of cortisol and low numbers of precocial offspring (Emera et al. 2012). To date, we have confirmed all of these features except method of trophoblast invasion in the spiny mouse (Quinn et al. 2013, Bellofiore et al. 2017). Notably, while the key reproductive and physiological features are common to menstruating species, none of these are exclusive to menstruating species. We discuss unexplored factors, which may have contributed to the evolution of menstruation later in this review.

\section{Menstruation and spontaneous decidualisation in other non-primate species}

Menstrual-like events, i.e. necrotic sloughing of endometrial tissue after failure to achieve pregnancy, have been documented in several non-primate species, but evidence of spontaneous decidualisation is inconsistent. The black mastiff bat (Molossus rufus) exhibits spontaneous decidualisation. However, in Pallas' long-tongued bat (Glossophaga soricina) and the shorttailed fruit bat (Carollia perspicillata), while post-ovulatory thickening of the endometrial stroma is documented to occur, decidual characteristics of these endometrial cells could not be confirmed (Hamlett 1934, Rasweiler \& De Bonilla 1992). Furthermore, endometrial shedding in G. soricina is confined to a single bleeding event per annum (Hamlett 1934).

Vascular remodelling of the arterioles in the endometrial basalis in G. soricina does not embody the typical angiogenesis and diverge into the functionalis, as in primates (Rasweiler 1991). Rasweiler's study also reported that recently mated female $C$. perspicillata often exhibited endometrial shedding despite the oviducts containing early-stage pronuclear zygotes to 8-cell embryos; when in other menstruating species, the uterus would be in the early secretory phases at the time when an embryo was present in the oviducts. Rasweiler suggests menstruation would be a means of eliminating differentiated endometrium or defective embryos during the breeding season and permits females another chance to mate if a successful pregnancy was not achieved.

Similarly, menstruation in Elephantulus typically only occurs at the end of the breeding season (Jul-Jan). Preparation for implantation in the eastern rock elephant shrew (Elephantulus myurus) also differs from the typical spontaneous decidual reaction seen in primates. Rather than transformation of the functionalis in its entirety, a single polyp forms, stemming from oedematous endometrium at the restricted caudal site of implantation in 

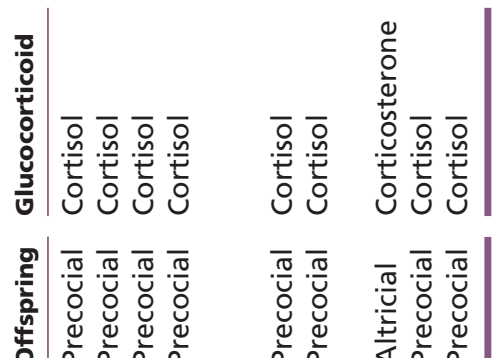

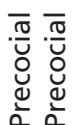
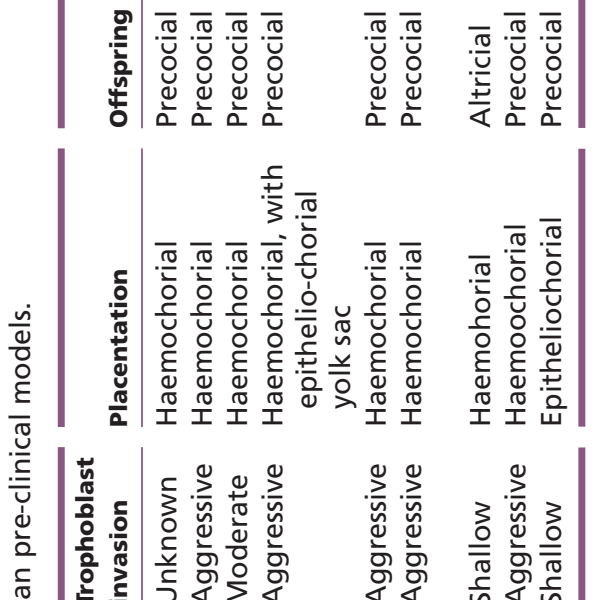

\section{|}

气 กับ

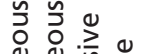

\section{n}

들 (1)
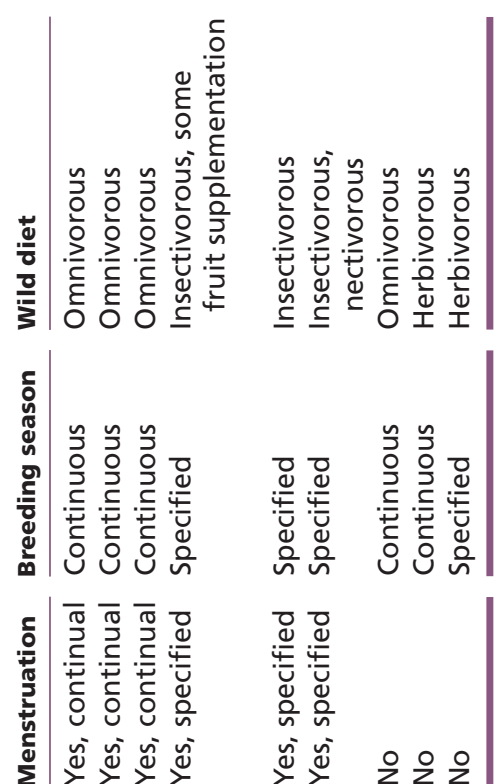

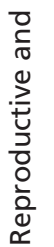
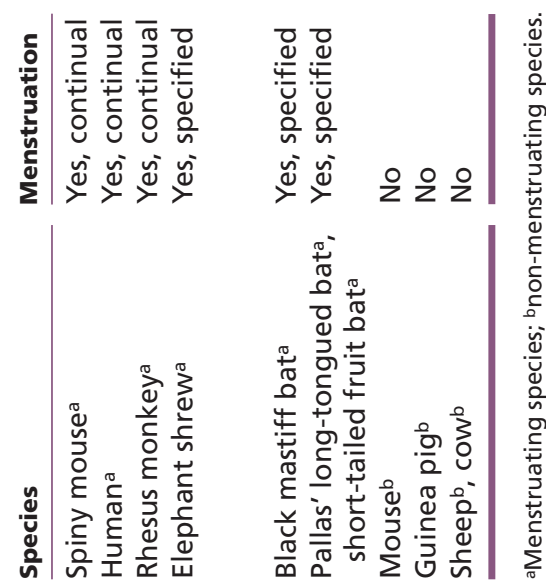
http://jme.endocrinology-journals.org
https://doi.org/10.1530/JME-17-0278 http://jme.endocrinology-journals.org
https://doi.org/10.1530/JME-17-0278 each uterine horn, to later give rise to an embryo chamber. Often in these instances, a decidual reaction is absent until a blastocyst is engulfed in the chamber itself, though not having yet implanted. (Van der Horst 1949). While elephant shrews exhibit haemochorial placentation, the embryo chamber later also gives rise to a yolk sac, which in fact has been suggested to be an epitheliochorial secondary placenta. If pregnancy is successful, this chamber envelopes the conceptus in a capsule-like structure, the decidua pseudocapsularis. If pregnancy is not achieved, the polyp is shed in a necrotic process akin to menstruation (Van der Horst 1949, Oduor-Okelo et al. 2004). Van der Horst and Gillman (1941) were unable to keep large cohorts of elephant shrews alive in captivity. They postulated females were polyoestrous during spring and summer, and ceased breeding in cooler months, but were unable to confirm accurate menstrual cycle lengths of these species.

The lack of continuous menstrual cycles throughout the year and inconclusive evidence of cyclical spontaneous decidualisation renders the elephant shrew and shorttailed fruit bat inappropriate translations for human menstrual studies.

\section{Seasonal breeding and oestrous cycles in the spiny mouse}

The spiny mouse is, to our knowledge, the only rodent with a natural, recurring menstrual cycle and may prove to be highly useful as a non-primate animal model. Interestingly, our data showing 9-day menstrual cycle (ranging 6-10 days) (Bellofiore et al. 2017) conflict with the previous report of an 11-day oestrous cycle (ranging from 6 to 18 days) in A. cahirinus (Peitz 1981). Female spiny mice in the previous cohort were fed a high-energy diet (sunflower seeds, rolled oats, Purina cat chow) and weighed $60-80 \mathrm{~g}$, double the weight of reproductively aged females in our colony (30-40g). There is evidence in human cohorts of significant increases in overall menstrual cycle length with increased female weight, and indeed amenorrhoea (absence of periods) has been observed on obese women (Harlow \& Matanoski 1991, Wei et al. 2009, Seif et al. 2015). In addition, the age of females within the Peitz study was not specified. These spiny mice may not, therefore, have been cycling regularly due to either pre-/peri-pubertal or advanced age.

A substantial difference in environmental temperature between the two studies is also noted; our colony of A. cahirinus is maintained at $25-26^{\circ} \mathrm{C}$ with the previous study (Peitz 1981) maintained at $22.5^{\circ} \mathrm{C}$. A. cahirinus is a desert species, and as such is acclimatised 
to warmer conditions, female spiny mice subjected to cooler temperatures may have experienced amenorrhea. South African spiny mice (Acomys spinosissimus), a related species, breed seasonally during spring (Sep-Jan), but are anovular and have reduced circulating progesterone levels and lactation between February and August, when temperatures decline below $20^{\circ} \mathrm{C}$ (Medger et al. 2010). There are very few studies on factors influencing female reproduction in wild $A$. cahirinus populations. A more recent study comparing the effects of photoperiod length on golden (Acomys russatus, xeric or dry desert species) and common (A. cahirinus, mesic or moist desert species) spiny mice by Wube et al. (2008) showed females of both species were unaffected by changes in photoperiod; both species maintained gonadal function under long and short photoperiods. Females of both species were of similar ages (3-4 months) to those in our study, but while vaginal lavages were conducted to monitor the cycle of females, they were only done so every 3 days, and cytology was analysed using methylene blue. It is also possible that by using methylene blue in lieu of haematoxylin and eosin, cytological signs of menstruation, comprising of dense, eosinophilic mucus, erythrocytes and cellular debris may have been overlooked. The authors of this study suggest that $A$. cahirinus could be an opportunistic breeder, capable of reproducing yearround (Wube et al. 2008). This suggests the common spiny mouse behaves like typical menstruating species and is unrestricted by seasonal breeding.

We can deduce that photoperiod is not the key driver of reproduction in this species of spiny mouse and also that either other Acomys do not menstruate at all or do not exhibit frank menses. Why then has only one species of spiny mouse evolved over menstruation? It may be that captive breeding over generations with removal of predators and stable nutrition allowed menstruation to evolve. It is a possibility that related cortisol-producing species who also have precocial young and a haemochorial placenta would adapt in the same way given the same opportunities. To better comprehend this concept, we must assess all species and theories regarding evolution of menstruation with the added knowledge of the biology of the common spiny mouse.

\section{Leading theories for the evolution of menstruation}

\section{Menstruation for screening of defective embryos}

Intercourse for menstruating species is not bound by restricted periods of heat. It remains to be confirmed whether wild $A$. cahirinus are also capable of year-round mating (as seen in our captive breeding colony), and whether copulation outside of breeding seasons are a unique trait to this species. For orangutans, chimpanzees and humans, mating can be initiated during any time of the menstrual cycle. However, full implantation of the embryo relies on appropriate epithelial changes and, importantly, decidualisation of endometrium. The decidual response is believed to serve a balance of two purposes in menstruating species: (1) to modulate the depth of trophoblast invasion as a means of maternal protection - negative regulation or anti-invasive and (2) to form a micro-environmental niche encouraging implantation and averting rejection - positive regulation or pro-invasive (Modi et al. 2012). This is facilitated by an influx of uterine natural killer (uNK) cells in response to secretion of chemoattractants from the decidualised endometrium (including IL-6, IL-11, IL-15, LIF and IGFBP1 ), and possibly from endometrial synthesis of prolactin, in the secretory phase of the menstrual cycle (Modi et al. 2012, Robson et al. 2012). The uNK cells surround the spiral arterioles, which is the location of decidualisation initiation, to promote vessel remodelling through secretion of angiogenic factors (Ang-1 and -2, VEGF and MMPs), during early gestation and in non-pregnant decidualised cells during the secretory phase (Smith et al. 2009, Robson et al. 2012). The spiny mouse demonstrates many of these characteristics of decidualisation, including typical immune cell recruitment and secretion of hallmark pro-invasive factors, including prolactin (Bellofiore et al. 2017) and IL-11 (N Bellofiore, S Rana, F Cousins, H Dickinson, P Temple-Smith, J Evans, unpublished observations). This is opposed to oestrous species, which require a signal transmitted from a viable conceptus to initiate the decidual reaction when displacement of the luminal epithelial cells of the endometrium occur by the implanting trophoblast (Abrahamsohn \& Zorn 1993, Clarke 1994, Emera et al. 2012).

Because the uterus is already primed for implantation, this results in an increased likelihood that a chromosomally abnormal embryo, produced by the union of potentially aged or reduced quality gametes, can in fact implant (Clarke 1994). The proportion of first trimester miscarriages in women due to genetic irregularities is 50-60\% (Wasser $\&$ Barash 1983), and up to $90 \%$ of cleavage-stage human embryos from otherwise fertile young women, have mitotic chromosomal abnormalities.

In healthy females, the ESFs of women can discriminate embryo quality after differentiation into DSCs (Teklenburg et al. 2010). Salker and associates (2010) 
hypothesised that women with recurrent pregnancy loss (RPL), defined as three or more consecutive miscarriages, would likely have an impaired decidualised endometrium, unable to distinguish between healthy and developmentally defective embryos at the time of implantation. Salker et al. demonstrated through culturing of ESCs from patients presenting with RPL that upon standard in vitro decidualisation, RPL decidual cells had significantly reduced expression of prolactin (PRL), a classic decidual biomarker, but increased expression of prokineticin-1 (PROK1), imperative in embryonic reception and implantation. They went on to show treatment with hCG in RPL women had opposing effects seen in control patients, resulting in prolonged induction of PRL and PROK1 and enhanced uterine receptivity (Salker et al. 2010). This incited the theory of a prolonged 'window' of time during which an embryo could implant, resulting in a decreased selectivity for abnormal embryos.

Dysregulation of the endometrial decidua, therefore, significantly damages fetal-maternal interactions, and results in promotion of implantation, even of poorquality embryos. Given the evidence of the dual roles of both pro- and anti-invasive regulation of the embryo by the decidualised cells, it may be that the risk of poorquality embryo implantation is a fundamental driver for the evolution of menstruation. We could consider that menstrual shedding of terminally differentiated DSCs may provide a secondary 'fail-safe' mechanism, by which embryos incapable of establishing connections to the maternal blood supply, in a timely progression as would a viable embryo, could be removed with the decaying decidua.

\section{Menstruation as a non-adaptive consequence of spontaneous decidualisation}

The most current theory speculates that the answer lies within spontaneous decidualisation, which is thought to have emerged through genetic assimilation caused by conflict between the mother and foetus (Emera et al. 2012, Renfree 2012) and is a maternal-protective adaptation in the evolutionary 'tug-of-war' between the conflicting survival interests of each (Finn 1996, Emera et al. 2012, Gundling \& Wildman 2015). Emera and colleagues further argue that menstruation is a non-adaptive consequence of spontaneous decidualisation. The shedding of the differentiated endometrial decidual cells results in breakdown of the tissue matrix, containing the increased number of blood vessels. With the structural integrity of the stroma surrounding these arterioles lost, the blood is expelled into the uterine lumen. This is the menstrual bleeding we observe; an adaptation of no specific benefit, but an indirect result of the evolution of spontaneous decidualisation.

The non-adaptive evolution of menstruation hypothesis is supported by observations in women, other catarrhine primates, the spiny mouse and the black mastiff bat (Molossus rufus) (Rasweiler 1991, Gellersen \& Brosens 2014, Carter et al. 2015, Bellofiore et al. 2017), but sufficient evidence of a spontaneous decidual reaction is conflicting in the elephant shrew and short-tailed fruit bat (van der Horst 1949, Rasweiler \& De Bonilla 1992).

\section{Unravelling the mystery of menses with clues from the spiny mouse: decidualisation, progesterone and prolactin}

We can say with certainty that progesterone decline is inherently important for initiation of endometrial breakdown in humans, higher order primates, the spiny mouse and the fulvous fruit bat (Brosens \& Gellersen 2006, Zhang et al. 2007, Emera et al. 2012, Bellofiore et al. 2017), though hormonal data are not available in other bat species. When serum progesterone levels are compared across mammalian species (Table 2), we note distinctive patterns in the progesterone increases during the luteal phase (where data are available). Although variations exist in blood sample collection and detection methods, a distinct trend is evident: all menstruating species have a $>3$-fold increase in maximum circulating serum progesterone in the luteal phase compared to the maximal levels detected in the follicular phase. In contrast, non-menstruating species have $<3$-fold increase in maximum circulating serum progesterone compared to maximal levels detected in the follicular phase, and in some species (mouse, rat, guinea pig, sheep), no increase in serum progesterone is apparent. We suggest that the high ratio of luteal to follicular phase serum progesterone may represent a characteristic, which is unique to menstruating species.

The high levels progesterone necessary to induce a spontaneous decidual reaction has certainly influenced other aspects of menstruating species' hormonal profiles during the luteal phase. Where data are available, we note that some menstruating species have a noticeable secondary surge of prolactin during their late luteal phase - including the spiny mouse (refer to Table 3 and Supplementary data, see section on supplementary data given at the end of this article), as opposed to the mouse, rat and sheep, which do not (Table 3). Prolactin, a peptide 
Table 2 Approximate comparative range of plasma progesterone levels ( $\mathrm{ng} / \mathrm{mL})$ in common mammals.

\begin{tabular}{|c|c|c|c|c|c|}
\hline Species (reference) & Blood collection & $\begin{array}{l}\text { Detection } \\
\text { method }\end{array}$ & $\begin{array}{c}\text { Early follicular } \\
\text { phase }\end{array}$ & $\begin{array}{c}\text { Late luteal } \\
\text { phase }\end{array}$ & $\begin{array}{l}\text { Relative fold } \\
\text { increase }\end{array}$ \\
\hline $\begin{array}{l}\text { Spiny mouse (Bellofiore et al. } \\
2017)^{a}\end{array}$ & Cardiac puncture (S) & ELISA & $30-64$ & $70-199$ & 3.1 \\
\hline $\begin{array}{l}\text { Human (Sherman \& Korenman } \\
\text { 1975)a }\end{array}$ & Venipuncture (R) & RIA & $1-5$ & $12-25$ & 5.0 \\
\hline $\begin{array}{l}\text { Rhesus monkey (Monroe et al. } \\
\text { 1970)a }\end{array}$ & Femoral (R) & CPB & $0-1$ & $2-6$ & 6.0 \\
\hline Baboon (Su et al. 1980)a & Saphenous/antecubita (R) & RIA & $0-1$ & $3-6$ & 6.0 \\
\hline $\begin{array}{l}\text { Fulvous fruit bat (Zhang et al. } \\
\text { 2007)a }\end{array}$ & Unspecified (R) & RIA & $0-1$ & $1-3$ & 3.0 \\
\hline Mouse (Nelson et al. 1981)b & Retro-orbital puncture (S) & RIA & $2-3$ & $1-2$ & - \\
\hline $\begin{array}{l}\text { Guinea pig (Croix \& } \\
\text { Franchimont 1975) }\end{array}$ & Decapitation (S) & RIA & $1-9$ & $2-7$ & - \\
\hline Sheep (Thorburn et al. 1969)b & Jugular (R) & CPB & $0-2$ & $1-3$ & 1.5 \\
\hline Rat (Butcher et al. 1974) ${ }^{b}$ & Decapitation (S) & CPB & $5-53$ & $2-27$ & - \\
\hline
\end{tabular}

Collections are Single (S) or Repeated (R) samples from individual subjects. Early follicular and late luteal phases in menstruating species correspond to proestrus and diestrus in non-menstruating species, respectively. Relative fold increase refers to fold increase in progesterone maximum values in late luteal phase compared to maximum values in early follicular phase. For ease of comparison, values have been rounded to nearest whole number. Values are approximated based on original data available.

aNon-menstruating species; bmenstruating species.

$\mathrm{CPB}$, competitive protein-binding assay; ELISA, enzyme-linked immunosorbent assay; RIA, radioimmunoassay.

hormone long thought to be primarily synthesised in the pituitary and involved in mammary gland development and lactogenesis, can also be synthesised in other organs including the uterus and placenta and is known to play key roles in corpus luteum maintenance and immune surveillance.

In the human endometrium, prolactin synthesis coincides with decidualisation during the secretory/luteal phase and is essential for progesterone synthesis during early pregnancy in most mammals. The role of prolactin in maintaining the corpus luteum differs between species and type of reproductive cycles. In some species, prolactin exerts a luteotrophic effect. Prolactin sustains progesterone production by the thecal- and granulosalutein cells by inhibiting the catalysis of biologically inactive progesterone by enzyme 20-alpha-hydroxysteroid dehydrogenase (Rothchild 2013). However, prolactin can also be luteolytic, such as in the guinea pig, and in the rat, prolactin can exert both luteotrophic and luteolytic properties. The contradictory actions of prolactin have been further explored in terms of angiogenesis, whereby intact human prolactin exerts an angiogenic effect, but

Table 3 Approximate comparative ranges of plasma prolactin levels in common mammals.

\begin{tabular}{|c|c|c|c|c|c|c|}
\hline & Blood collection & Detection method & $\begin{array}{l}\text { Proestrus/early } \\
\text { follicular }\end{array}$ & $\begin{array}{l}\text { Oestrus/late } \\
\text { follicular }\end{array}$ & $\begin{array}{l}\text { Metestrus/early } \\
\text { luteal }\end{array}$ & $\begin{array}{c}\text { Diestrus/late } \\
\text { luteal }\end{array}$ \\
\hline Spiny mouse* & Cardiac puncture (S) & DXI immunoassay & $3.3 \pm 4.1$ & $10.0 \pm 7.9$ & $5.0 \pm 5.0$ & $11.7 \pm 2.6^{c}$ \\
\hline $\begin{array}{l}\text { Human (Halbreich } \\
\text { et al. 1976)a }\end{array}$ & Venipuncture (R) & RIA & $11-13$ & $17-28$ & $14-22$ & $24-34$ \\
\hline $\begin{array}{l}\text { Rhesus monkey* } \\
\text { (Jahan et al. } \\
\text { 2007)a }\end{array}$ & Saphenous (R) & EIA & $151-176$ & $213-239$ & $273-285$ & $365-485$ \\
\hline $\begin{array}{l}\text { Mouse (Sinha et al. } \\
\text { 1975)b }\end{array}$ & Decapitation (S) & RIA & $78-90$ & $95-115$ & $75-91$ & 89-99 \\
\hline $\begin{array}{l}\text { Sheep (Kann \& } \\
\text { Denamur 1974)b }\end{array}$ & Jugular (R) & RIA & $200-300$ & $500-600$ & $7-40$ & $10-40$ \\
\hline $\begin{array}{l}\text { Rat (Butcher et al. } \\
\text { 1974) }\end{array}$ & Decapitation (S) & RIA & $12-291$ & $12-330$ & $12-35$ & $12-76$ \\
\hline
\end{tabular}

Values are $\mathrm{ng} / \mathrm{mL}$ excluding $\left(^{*}\right)$ where values are IU/L. Values are approximated based on original data available, except for the spiny mouse where values are mean \pm S.D. based on raw data. Full details of DXI Immunoassay can be found in supplementary information. Collections are Single (S) or Repeated (R) samples from individual subjects. For ease of comparison, values have been rounded to nearest whole number. aMenstruating species; bnon-menstruating species; cdenotes $P<0.05$ compared to early follicular phase (ANOVA). EIA, enzyme immunoassay; RIA, radioimmunoassay. 
$\mathrm{N}$-terminal fragments are antiangiogenic (Struman et al. 1999). The potential role of prolactin in delaying corpora lutea regression and perpetuating the active luteal phase in menstruating species requires further exploration.

There is increasing evidence that prolactin is important in immune system regulation. Gubbay and associates identified novel targets in the prolactin signalling pathway; prolactin receptor-positive cells were present on uterine natural killer cells (Gubbay et al. 2002), employing mitogenic actions. Uterine natural killer cells are the primary leukocyte recruited during the secretory phase of the menstrual cycle.

Decidual prolactin secretion likely plays a role in immune surveillance during the menstrual cycle and supports the theory that spontaneous decidualisation evolved to screen for embryo viability. Menstruating species all possess high maternal investment in their offspring, as well as invasive placentation. For these species, any mating that occurs outside oestrus (even if only by a couple of days) could increase the probability of poorer quality gametes meeting. Given the high demands of nutrient and blood supply from the offspring, devoting energy and resources in inferior offspring is a substantial maternal risk. Prolactin could circumvent this from occurring in the following ways: (1) upregulating immunosurveillance by increasing recruitment of natural killer cells to the endometrium in preparation for the impending allogeneic pregnancy, and for these natural killer cells to then aid in adequate spiral arteriole remodelling and (2) to increase angiogenesis in preparation for aggressive trophoblast invasion.

\section{Why would spontaneous decidualisation evolve in some species but not others?}

We can reasonably infer so far that cyclical menstruation and spontaneous decidualisation are not mutually exclusive events. We can also postulate that spontaneous decidualisation evolved in species that produce cortisol to protect against implantation of lower quality embryos arising from unrestricted breeding year-round.

But why would mating evolve independent of season in these precocial species? To shed some light on one of biology's greatest peculiarities, we must examine every aspect of conceivable relevance. At first, there are seemingly few clues linking the chain of menstruating species together, which explain why, in this handful of geographically diverse mammals, menstrual cycles evolved in lieu of oestrous cycles. It is remarkably difficult finding common ground in the biology and/or ecology of menstruating species that is in fact, unique to only menstruating species. The authors here scrutinised as many potential areas of interest as possible and found little connection in the way of mating and parental care (e.g. hierarchical, monogamous, communal), male penile anatomy (e.g. spindled in the spiny mouse vs smooth in humans), female size (ranging from a $35 \mathrm{~g}$ spiny mouse to a $75 \mathrm{~kg}$ human), female uterine anatomy (e.g. the bicornuate horns of the spiny mouse vs. the fundal body of higher order primates) or average litter size (e.g. spiny mouse $2-3$ vs primates, bats $1-2$ ). However, one key factor requiring further exploration is diet.

A link between the natural diets of these species is initially unclear. Baboons, chimpanzees, rhesus monkeys and orangutans derive a majority of their energy from fruits, though foods range from seeds and flowers, to invertebrates and on occasion, small vertebrates. However, others are primarily nectar and fruit based (fruit bats and Pallas' long-tongued bat) or insectivorous, such as the elephant shrew and the black mastiff bat, surviving on insects and worms, with occasional fruit and plant matter (The International Union for Conservation of Nature and Natural Resources 2015). In the human's case, almost nothing is off limits. To complicate the mix, we now add the common spiny mouse who feasts on grubs, insects and dates (Encyclopaedia Britannica 2017). But perhaps this variation in diet provides a clue? Is it coincidence that no solely herbivorous or carnivorous menstruating species have been found? It is possible that it is not the type of diet of the mammals as such, but the availability and continual supply of energy, which may have enabled spontaneous decidualisation to evolve in precocial species.

Fruit, a major dietary component of primates and bats, and supplementary to the diets of shrews and spiny mice, are high in sucrose and fructose, and also in fibre, slowing its passage through the gastrointestinal tract and allowing more time to breakdown sucrose into glucose. In addition, fructose is metabolised to glucose in the liver, without the need for an insulin response (Lehninger et al. 2008). This ultimately means that the glucose from ingestion of fruit can be utilised for energy longer than other carbohydrate sources, such as starch, which would provoke an insulin response upon digestion and encourage the conversion and storage of glucose to glycogen. Fruit is not only a superior source of energy, but also is a food source available year-round in the natural habitats of the aforementioned species. Similarly, insects are not merely a source of high protein, but also moderate to high in unsaturated fats and essential fatty acids, particularly larvae (Van Huis et al. 2013). Most menstruating species supplement their 
diet with insects, minimising the risk of starvation or fasting should fruit and flowers be unavailable. However, perhaps a highly variable omnivorous diet could in fact become detrimental for reproduction in the ancestors of menstruating species. Nutrition is a critical element in determining breeding seasons in oestrous cycle species, as the timing of birth needs to coincide with periods of abundant food to support a lactating mother and growing neonate (Downey 1980). With the continual supply of energy, it could be that stability in nutrition throughout seasons lead to an absence of an external trigger in these species; that is, without any change in food availability, females were not environmentally stimulated to commence breeding. So, rather than these species never receiving the signal to mate, they are able to do the opposite: mate continuously throughout the year. Hence, spontaneous rather than induced ovulation evolved, but so too did the risk of mating outside of oestrus. With the potential for pregnancy to occur from the formation of poorer quality gametes, these species required a mechanism to protect maternal resources from investing in nonviable offspring, i.e. spontaneous decidualisation. The persistent cyclical differentiation and maintenance of decidualised endometrium is, however, energetically costly. But with a considerably adaptable diet, obtaining adequate nutrients to do maintain a decidual reaction is achievable. This may aid in explaining why some mammals that share many characteristics of menstruating species (e.g. guinea pig) but do not exhibit spontaneous decidualisation: the high metabolic demands of maintaining such a reaction is not satisfied by their diet, due to unpredictable or limited seasonal food availability. It may also explain why some primarily insectivorous menstruating species are still dictated by breeding seasons, as a lack in variable dietary intake may not allow for constant cyclic sustention of decidua. Figure 2 summarises our hypothesis on the evolution spontaneous decidualisation and subsequent menstruation taking into consideration dietary preferences and endocrinological profiles of menstruating species.

Decidualisation requires increased energy. Reproductive anthropologists have speculated that menstrual cycles have evolved because cyclical shedding and renewal are less energetically costly than maintaining differentiated and metabolically demanding endometrium required for implantation. Food consumption in menstruating primates has been shown to peak during the luteal phase, but not in oestrous species such as rodents (Dye \& Blundell 1997). The most extreme examples of this are observed in menstruating species where 6 days' worth of food requirements can be saved over 4 cycles during

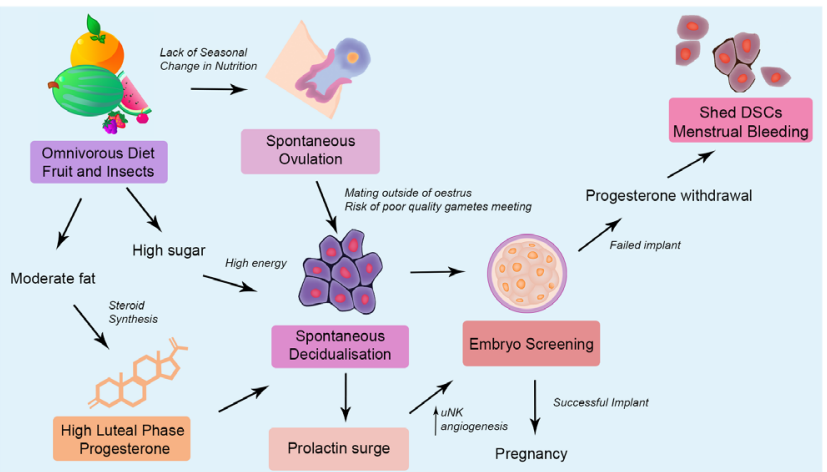

Figure 2

Proposed role of nutrition in the evolution of spontaneous decidualisation and menstruation. uNK, uterine natural killer cells; DSCs, decidualised stromal cells.

the follicular phase (Strassmann 1996). A supporting study showed a $2 \%$ increase in fat consumption in women during the late luteal phase compared to the preovulatory follicular phase (Johnson et al. 1994). Based on the high levels of progesterone required to maintain a decidual reaction, an increase in fat consumption is likely due to the body's increasing demand for cholesterol and steroidogenesis. This, in conjunction with the dietary preferences of mammals which terminally differentiate their endometrium, coincides with reports of women experiencing increased severity of food cravings and carbohydrate intake during their premenstrual phase, with particular reference to those experiencing symptoms of premenstrual depression (Wurtman et al. 1989).

\section{Current pre-clinical models for the study of menstruation and menstrual disorders}

Reproductive complications exclusively associated with menstruation are pronounced in humans abnormal uterine bleeding (AUB), which includes heavy menstrual bleeding ( $>80 \mathrm{~mL}$ blood loss and/or more than 7 days of bleeding), are experienced by up to $30 \%$ of women (Liu et al. 2007, Knight et al. 2009), with reports in the United States of America of over $63 \%$ of these patients electing to undergo surgical treatment such as hysterectomy (Jensen et al. 2012), and an estimated annual indirect cost of $\$ 12$ billion (Liu et al. 2007). In addition, Liu et al. (2007) demonstrated AUB patients received scores below the 25th percentile for health-related quality of life in categories such as pain, mental health, physical and social function. For these often silent sufferers, diagnosis and treatments are frequently reduced to invasive surgery, ineffective medications or else go untreated. This stems 
from our limited understanding of the pathophysiological mechanisms of these conditions.

Studies of true, natural menstruation and related conditions are restricted to women and higher order primates and both present with ethical, cost and resource concerns. The lack of a large scale, cost-effective and translational animal model has slowed our understanding of menstruation and menstrual-associated disorders and limited progression of therapeutic developments in this field.

To overcome these issues, researchers have developed artificial models of menstruation. Exogenous administration of reproductive hormones, in an attempt to mimic the hormonal cycling in humans, have been used in mice which, under specific conditions can be induced to undergo a menstruation-like event (Brasted et al. 2003, Rudolph et al. 2012). The first report by Finn and Pope of an induced mouse model of menstruation described the induction of decidualisation and menstruallike breakdown of the endometrium after cessation of exogenous hormonal administration (Finn \& Pope 1984). This model was later refined with administration of daily oestradiol-17B for 3 days after ovariectomy, followed by insertion of a progesterone-releasing implant and induction of decidualisation via oil injection into the uterine horn. Rapid withdrawal of progesterone support after implant removal led to a menses-like event, with a loss of tissue integrity from 4 to $8 \mathrm{~h}$ post progesterone removal followed by extensive shedding of endometrial tissue between 16 and 36 h (Brasted et al. 2003, Wang et al. 2013, Cousins et al. 2014). This development of a mouse model of menstruation overcame the ethical issues and high cost of husbandry and resources of primate models and provided a significant advance in women's reproductive research. While the substantial increase in progesterone is mimicked in the induced mouse model of menstruation, these species have not evolved an accompanying behavioural response to increase their energy intake to support such a reaction, as menstruating species do (Johnson et al. 1994, Strassmann 1996, Dye \& Blundell 1997). This is likely one of the key contributing factors as to the necessity for artificial stimulation of the uterine decidual reaction. Moreover, the use of an ovariectomised model eliminates other important endocrine interactions, which are vital to our understanding of this complex physiological process. A lack of ovarian structures, including a corpus luteum, limits the translation of this model. For example, progesterone has been suggested to be autoregulatory, in that its secretion from the corpus luteum in fact perpetuates further synthesis (Rothchild
1981); mechanisms that cannot be mirrored in a model without lutein cells. Such hormonal pathways are still largely unexplored and ill understood, and therefore, present limitations for our reliance on induced models.

The mouse model has enabled a new understanding of the events of menstrual breakdown, and the key roles of steroidogenic input (Wang et al. 2013, Cousins et al. 2016). Efforts have been made to further refine this model and adapt it for studies of endometriosis by intraperitoneal injection of mouse or human menstrual tissue suspension (Bruner-Tran et al. 2009, Greaves et al. 2014). Endometriosis is a disorder of inflammation and endocrinology, which affects around 1 in 8 women of reproductive age worldwide. It has also been observed with similar clinical pathologies in non-human primates, including rhesus monkeys and baboons (Merrill 1968, McCann \& Myers 1970, Folse \& Stout 1978), and in up to $25 \%$ of individuals in captive baboon populations (D'Hooghe et al. 1991). Although the pathophysiology of endometriosis is not completely understood, one of the leading theories suggests it is caused by retrograde menstruation. Retrograde menstruation is the process wherein shed menstrual debris may be forced up the reproductive tract, through the fallopian tubes and into the peritoneal cavity (Sampson 1927). Here, endometrial tissue fragments seed onto organs leading to formation of endometriotic lesions, which may even bleed at the time of menstruation (Laux-Biehlmann et al. 2015). By definition, only menstruating species naturally develop this disorder.

Development of a small animal model, which exhibits ectopic endometrial lesions comparable phenotypically and histologically to those in women and demonstrating similar inflammatory reactions significantly advance our ability to study the pathophysiology of a poorly understood, yet highly prevalent disorder. However, despite the initial success of the induced mouse menstrual endometrium, it is not a physiologically appropriate representation of normal human menstrual events. Collection of menstrual debris through scraping of the inner uterine horn inevitably increases the probability that not only the functionalis (the superficial endometrial layer, which is shed during menstruation in humans) will be collected, but also underlying basalis, which is not shed but aids in endometrial repair, and likely myometrial tissue as well. Given that quantity of basalis and myometrial cells cannot be controlled using this method and are not shed during true menstruation, this model is not ideal physiological mimic of natural menstruation in the human. 
Additionally, although it is possible to induce a menstruation event in the mouse model, the lack of recurrent menstrual cycling ultimately means not only can the individual animals not be assessed over multiple cycles, but the model will not have natural uterine pre-conditioning, nor the diseases arising from impaired decidualisation. The mouse model also does not show vascular remodelling and hence is not able to model diseases such as pre-eclampsia, placenta accreta or recurrent miscarriage due to inadequate angiogenesis of the spiral arterioles. This emphasises the important research and clinical translation benefits of the newly discovered spiny mouse small animal model of true menstruation.

Non-human primates are ideal in terms of translation of menstrual mechanistic and disorder research to humans, due to their similarity in timing of menstrual cycles (ranging from 21 to 40 days) and the anatomy of the reproductive tract; a simplex uterus with one fundal body as opposed to the rodent duplex uterus (including the spiny mouse) with separate uterine horns. However, in research, a duplex uterus may also have an advantage for experimental purposes in providing a control and treated uterus in the same individual.

Primates have been used to study menstruation and menstrual disorders, including premenstrual syndrome (PMS). PMS is experienced by up to $75 \%$ of women and can disrupt daily function and maintenance of interpersonal relationships. In extreme cases, $10 \%$ of women exhibit symptoms of premenstrual dysphoric disorder (PMDD) and may experience recurring clinical depression and psychological distress around the time of menstruation (Reid 1991). PMS-like symptoms closely mimicking those seen in humans were first observed in baboons in captive females (Hausfater \& Skoblick 1985). They confirmed female baboons displaying social withdrawal, increased solitude and increased eating prior to menstrual onset in wild populations in Kenya; the first observation of PMS in a non-human species. This important observation was among the first scientific evidence to affirm that PMS was not merely a psychological incidence, but stemmed from hormonal fluctuations, leading to greater awareness of PMS as a genuine condition. However, ethical requirements and substantial financial costs involved in the maintenance and care of research populations of nonhuman primates have limited the number of animals in captivity and restricted progress in these studies. Wild population studies while less invasive for the animals are complicated in terms of long-term research. The study in Kenya, reported on a large group of females, but long-term assessment of individual female behaviour to determine whether symptoms are recurring or similar in magnitude for each baboon was not possible. Here, the spiny mouse could serve as an invaluable research commodity for repeated measure, long-term studies on individual females across their menstrual cycles.

\section{The spiny mouse and the future of menstrual research}

Previous work surrounding numerous aspects of reproduction and pregnancy in $A$. cahirinus has demonstrated the capacity for this species to be invaluable for translational research. Initially established in 1986 by Lamers and colleagues, the spiny mouse produces cortisol as its circulating glucocorticoid, as opposed to murine relatives synthesising corticosterone. The resultant changes in the timing of organogenesis in the spiny mouse, in which offspring maturity on the day of birth equates to that of the rat during its second to third postnatal week, appoints the spiny mouse as a preferred rodent model of precocial development analogous to the human gestational condition (Lamers et al. 1986). The benefits of using a species in which postconceptual maturation is delayed in mid gestation, by contrast to altricial species, has been highlighted with particular reference to mechanisms that occur during development of the fetal brain (Brunjes 1989), kidney (Dickinson et al. 2005) and adrenal gland (with synthesis of DHEA in the fetal adrenal glands confirmed) (Quinn et al. 2013). Similarities between the placenta of the spiny mouse and primates have been established, with continual growth of the placenta throughout gestation, an increased ratio of labyrinth to spongy zone, and notable sex differences in genetic regulation of the former (O'Connell et al. 2013). Together, these findings have highlighted the underlying advantages of using the spiny mouse as a model to study placental and perinatal development and injury.

The newly discovered knowledge of a naturally occurring menstrual cycle in the spiny mouse in conjunction with its other shared features of primate reproduction has the potential for this species to be a powerful research tool for studying reproductive disorders. In addition to the disorders directly associated with regular tissue shedding, menstruating species are particularly vulnerable to diseases during pregnancy. The leading cause of maternal death worldwide (with a mortality rate of $10-15 \%$ ) is pre-eclampsia (Duley 2009), characterised by hypertension, poor angiogenesis and shallow invasion of the trophoblast into the uterine vasculature (Huppertz 
2014), with delivery of the placenta the only current treatment of this life-threatening disease.

While these diseases are referred to as human-specific conditions, correlations between abnormalities in the menstrual cycle and such disorders are likely to exist. Brosens et al. (2009) emphasises that the risk of preeclampsia and other obstetric complications is vastly increased in young (particularly adolescent), primiparous women. They suggest that this may be due to insufficient uterine and menstrual pre-conditioning. Uterine preconditioning is defined here as repeated exposure to cyclical breakdown and regeneration of the uterine tissues in tolerable measures, allowing for physiological preparation for the extreme invasiveness, oxidative stress, angiogenesis and inflammatory reactions of haemochorial placentation (Brosens et al. 2009). Spiral arteriole remodelling is significantly compromised in pre-eclamptic women, with impaired extravillous trophoblast invasion, resulting in a highly resistant, restricted blood flow to the placental tissues, presenting clinically as hypertension (Dekker \& Sibai 1998). DSCs are thought to be important through chemokine secretion in structural destruction of these arteries and the displacement of smooth muscle media to enable adequate penetration of the trophoblast cells. An inadequate decidual response or insufficient exposure to repeated shedding and repair in preparation for the extensive physiological toll of a highly demanding pregnancy is therefore hypothesised to be a key component of complications such as pre-eclampsia, and as such it is imperative we understand what constitutes an adequate decidual response during the menstrual cycle.

The possibilities of exploiting the natural menstrual cycle of a small, captive rodent species to study menstrual health and arising complications are unparalleled. Longterm studies analysing the changes to the menstrual cycle could give rise to a novel model of menopause, overcoming the current pitfalls of conventional laboratory species, such as rats and mice. These rodents experience reproductive ageing in quite a different manner to menstruating species, and cessation has a very sudden onset. In humans, the complex perimenopause transition is constituted by a gradual shortening and irregularity in menstrual cycles with trending hyperoestrogenic ovulations in many women, accelerated loss of oocytes and endocrinological changes unable to be experimentally mimicked in rodents, such as elevated DHEA sulphate (Finch 2014). The spiny mouse, being capable of synthesising DHEA and derivatives, may provide a more genuine model of steroid and adrenal androgen interactions during reproductive senescence.
The diversity of menstrual bleeding, cycle lengths, phases of the menstrual cycle and behaviour of the spiny mouse is prominent between individual females (Bellofiore et al. 2018). This natural variety reinforces the promise of the spiny mouse as a comparable imitation of the human menstrual cycle, and potentially through selective breeding, we could isolate females demonstrating extreme phenotypes and isolate models of HMB, oligomenorrhea, ovulatory dysfunction and potentially, PMS. The spiny mouse also appears to exhibit spiral arteriole remodelling with decidualisation initiating from these regions in the endometrium (Fig. 3), similar to humans, suggesting the possibility of spontaneous or induced model for preeclampsia during spiral artery remodelling.

The novelty of the spiny mouse, however, presents a variety of obstacles which need to be addressed before wide spread use of this relatively unexplored species is a reality. To date, our captive colony has not seen an introduction of new genetic material since first establishment in 2002, and the implications of this are not yet known. Genetic studies in the spiny mouse have, in the past, been a hindrance, with significantly less data available than frequently used species. Subsequently, specific reagents for research using common laboratory techniques relying on genetic sequencing, or immune-based reactions are lacking, which in turn may produce suboptimal results. Despite these temporary setbacks, we encourage the recognition and future incorporation of the spiny mouse as an invaluable asset in the field of women's reproductive health.

Whether or not the discovery of menstruation among a captive colony of spiny mice is reflective of a natural reproductive strategy in these species or if it has somehow evolved only in said colony, requires further investigation. Regardless, we find ourselves in an extraordinary position to manipulate these circumstances to our advantage and progress our understanding of menstruation.
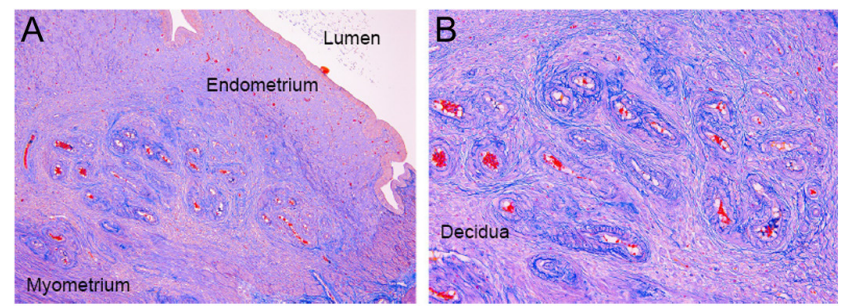

\section{Figure 3}

(A) Spiral arteriole remodelling (arrows) in the endometrium of the spiny mouse. $\times 100$ (scale bar 200 microns) and (B) decidualisation initiating around the formation of these spiral blood vessels (arrow). $\times 200$ (scale bar 100 microns). 


\section{Conclusion}

The first report of a small rodent model of menstruation provides an exciting prospect and important new direction forfuture research concerning women's reproductive health and fertility. Investigations are currently being conducted to determine the appropriateness of the common spiny mouse as a pre-clinical model for menstrual-associated diseases and pregnancy disorders. Further evidence is still required to support the leading theories of the evolution of menstruation as a non-adaptive consequence. We have determined the only discernible unique features specific to perennial menstruating species only, to our knowledge, are a high ratio of luteal:follicular phase progesterone required to maintain a spontaneous decidual reaction, and sustainable nutrition to compensate for the high energy demands of premenstrual decidua. We propose that spontaneous decidualisation has evolved in cortisolproducing species, including the spiny mouse, primarily as a means of embryo screening. We hope to attain more clues to the secrets of menstruation through the spiny mouse and its unique position as a humanesque rodent.

\section{Supplementary data}

This is linked to the online version of the paper at https://doi.org/10.1530/ JME-17-0278.

\section{Declaration of interest}

The authors declare that there is no conflict of interest that could be perceived as prejudicing the impartiality of this review.

\section{Funding}

N B is a recipient of a Research Training Program scholarship supported by Monash University. H D is a National Health and Research Council Career Development Fellow.

\section{Author contribution statement}

Nadia Bellofiore: Generation of content, review of literature, formation of ideas and hypotheses, building of figures, manuscript drafting and editing. Fiona Cousins: Content refinement, manuscript editing. Peter Temple-Smith: Content refinement, formation of ideas, manuscript editing. Hayley Dickinson: Manuscript editing. Jemma Evans: Generation of content, review of literature, manuscript drafting and editing.

\section{Acknowledgements}

The authors acknowledge the technical assistance of the histology facility at Hudson Institute of Medical Research. They sincerely thank Simon Pederick for his technological and software assistance.

\section{References}

Abrahamsohn PA \& Zorn TMT 1993 Implantation and decidualization in rodents. Journal of Experimental Zoology 266 603-628. (https://doi. org/10.1002/jez.1402660610)

Auletta FJ \& Flint AP 1988 Mechanisms controlling corpus luteum function in sheep, cows, nonhuman primates, and women especially in relation to the time of luteolysis. Endocrine Reviews 9 88. (https:// doi.org/10.1210/edrv-9-1-88)

Bellofiore N, Ellery SJ, Mamrot J, Walker DW, Temple-Smith P \& Dickinson H 2017 First evidence of a menstruating rodent: the spiny mouse (Acomys cahirinus). American Journal of Obstetrics and Gynecology 216 40.e41-40.e11. (https://doi.org/10.1016/j. ajog.2016.07.041)

Brasted M, White CA, Kennedy TG \& Salamonsen LA 2003 Mimicking the events of menstruation in the murine uterus. Biology of Reproduction 69 1273-1280. (https://doi.org/10.1095/ biolreprod.103.016550)

Brosens J \& Gellersen B 2006 Death or survival-progesterone-dependent cell fate decisions in the human endometrial stroma. Journal of Molecular Endocrinology 36 389-398. (https://doi.org/10.1677/ jme.1.02060)

Brosens JJ, Parker MG, McIndoe A, Pijnenborg R \& Brosens IA 2009 A role for menstruation in preconditioning the uterus for successful pregnancy. American Journal of Obstetrics and Gynecology 200615. e611-615.e616. (https://doi.org/10.1016/j.ajog.2008.11.037)

Bruner-Tran KL, Osteen KG \& Duleba AJ 2009 Simvastatin protects against the development of endometriosis in a nude mouse model. Journal of Clinical Endocrinology and Metabolism 94 2489-2494. (https://doi.org/10.1210/jc.2008-2802)

Brunjes P 1989 A comparative study of prenatal development in the olfactory bulb, neocortex and hippocampal region of the precocial mouse Acomys cahirinus and rat. Developmental Brain Research 49 7-25. (https://doi.org/10.1016/0165-3806(89)90055-2)

Butcher R, Collins W \& Fugo N 1974 Plasma concentration of LH, FSH, prolactin, progesterone and estradiol-17 $\beta$ throughout the 4-day estrous cycle of the rat. Endocrinology 94 1704-1708. (https://doi. org/10.1210/endo-94-6-1704)

Carter AM, Enders AC \& Pijnenborg R 2015 The role of invasive trophoblast in implantation and placentation of primates. Philosophical Transactions of the Royal Society B: Biological Sciences $\mathbf{3 7 0}$ 20140070. (https://doi.org/10.1098/rstb.2014.0070)

Clarke J 1994 The adaptive significance of menstruation: The meaning of menstruation in the elimination of abnormal embryos. Human Reproduction 9 1204-1207. (https://doi.org/10.1093/oxfordjournals. humrep.a138678)

Cousins FL, Murray A, Esnal A, Gibson DA, Critchley HO \& Saunders PT 2014 Evidence from a mouse model that epithelial cell migration and mesenchymal-epithelial transition contribute to rapid restoration of uterine tissue integrity during menstruation. PLOS ONE 9 e86378. (https://doi.org/10.1371/journal.pone.0086378)

Cousins FL, Kirkwood PM, Murray AA, Collins F, Gibson DA \& Saunders PT 2016 Androgens regulate scarless repair of the endometrial 'wound' in a mouse model of menstruation. FASEB Journal 30 2802-2811. (https://doi.org/10.1096/fj.201600078R)

Croix D \& Franchimont P 1975 Changes in the Serum Levels of the Gonadotrophins Progesterone and Estradiol during the Estrous Cycle of the Guinea Pig. Neuroendocrinology 19 1-11.

D'Hooghe TM, Bambra CS, Cornillie FJ, Isahakia M \& Koninckx PR 1991 Prevalence and laparoscopic appearance of spontaneous endometriosis in the baboon (Papio anubis, Papio cynocephalus). Biology of Reproduction 45 411-416.

Dekker GA \& Sibai BM 1998 Etiology and pathogenesis of preeclampsia: current concepts. American Journal of Obstetrics and Gynecology 179 1359-1375. (https://doi.org/10.1016/S0002-9378(98)70160-7) http://jme.endocrinology-journals.org https://doi.org/10.1530/JME-17-0278
(C) 2018 Society for Endocrinology Published by Bioscientifica Ltd. Printed in Great Britain 
Dickinson H, Walker DW, Cullen-McEwen L, Wintour EM \& Moritz K 2005 The spiny mouse (Acomys cahirinus) completes nephrogenesis before birth. American Journal of Physiology: Renal Physiology 289 F273-F279. (https://doi.org/10.1152/ajprenal.00400.2004)

Downey B 1980 Regulation of the estrous cycle in domestic animals - a review. Canadian Veterinary Journal 21301.

Druckmann R \& Druckmann M-A 2005 Progesterone and the immunology of pregnancy. Journal of Steroid Biochemistry and Molecular Biology 97 389-396. (https://doi.org/10.1016/j. jsbmb.2005.08.010)

Duley L 2009 The global impact of pre-eclampsia and eclampsia. In Seminars in Perinatology, pp 130-137. Elsevier: New york, USA. (https://doi.org/10.1053/j.semperi.2009.02.010)

Dye L \& Blundell J 1997 Menstrual cycle and appetite control: implications for weight regulation. Human Reproduction 12 1142-1151. (https://doi.org/10.1093/humrep/12.6.1142)

Emera D, Romero R \& Wagner G 2012 The evolution of menstruation: a new model for genetic assimilation. BioEssays 34 26-35. (https://doi. org/10.1002/bies.201100099)

Encyclopaedia Britannica 2017 African Spiny Mouse. Ed E Britannica. Chicago, USA: Encyclopaedia Britannica, Inc.

Evans J \& Salamonsen LA 2014 Decidualized human endometrial stromal cells are sensors of hormone withdrawal in the menstrual inflammatory cascade. Biology of Reproduction 90 14. (https://doi. org/10.1095/biolreprod.113.108175)

Ferenczy A 1980 Regeneration of the human endometrium. Progress in Surgical Pathology 1 157-173.

Finch CE 2014 The menopause and aging, a comparative perspective. Journal of Steroid Biochemistry and Molecular Biology 142 132-141. (https://doi.org/10.1016/j.jsbmb.2013.03.010)

Finn CA 1996 Why do women menstruate? Historical and evolutionary review. European Journal of Obstetrics and Gynecology and Reproductive Biology 70 3-8.

Finn C \& Pope M 1984 Vascular and cellular changes in the decidualized endometrium of the ovariectomized mouse following cessation of hormone treatment: a possible model for menstruation. Journal of Endocrinology 100 295-300. (https://doi.org/10.1677/joe.0.1000295)

Folse D \& Stout L 1978 Endometriosis in a baboon (Papio doguera). Laboratory Animal Science 28 217-219.

Gellersen B \& Brosens JJ 2014 Cyclic decidualization of the human endometrium in reproductive health and failure. Endocrine Reviews 35 851-905. (https://doi.org/10.1210/er.2014-1045)

Gonet AE, Stauffacher W, Pictet R \& Renold AE 1966 Obesity and diabetes mellitus with striking congenital hyperplasia of the islets of Langerhans in spiny mice (Acomys cahirinus). Diabetologia 1 162-171. (https://doi.org/10.1007/BF01257907)

Greaves E, Cousins FL, Murray A, Esnal-Zufiaurre A, Fassbender A, Horne AW \& Saunders PT 2014 A novel mouse model of endometriosis mimics human phenotype and reveals insights into the inflammatory contribution of shed endometrium. American Journal of Pathology 184 1930-1939. (https://doi.org/10.1016/j. ajpath.2014.03.011)

Gubbay O, Critchley H, Bowen J, King A \& Jabbour H 2002 Prolactin induces ERK phosphorylation in epithelial and CD56+ natural killer cells of the human endometrium. Journal of Clinical Endocrinology and Metabolism 87 2329-2335. (https://doi.org/10.1210/ jcem.87.5.8515)

Guernsey MW, Chuong EB, Cornelis G, Renfree MB \& Baker JC 2017 Molecular conservation of marsupial and eutherian placentation and lactation. eLife 6 e27450. (https://doi.org/10.7554/eLife.27450)

Gundling WE \& Wildman DE 2015 A review of inter-and intraspecific variation in the eutherian placenta. Philosophical Transactions of the Royal Society of London B: Biological Sciences 370 20140072. (https:// doi.org/10.1098/rstb.2014.0072)

Halbreich U, Ben-David M, Assael M \& Bornstein R 1976 Serumprolactin in women with premenstrual syndrome. Lancet $\mathbf{3 0 8}$ 654-656. (https://doi.org/10.1016/S0140-6736(76)92465-X)
Hamlett G 1934 Uterine bleeding in a bat, Glossophaga soricina. Anatomical Record 60 9-17. (https://doi.org/10.1002/ar.1090600104)

Harlow SD \& Matanoski GM 1991 The association between weight, physical activity, and stress and variation in the length of the menstrual cycle. American Journal of Epidemiology 133 38-49. (https:// doi.org/10.1093/oxfordjournals.aje.a115800)

Hausfater G \& Skoblick B 1985 Perimenstrual behavior changes among female yellow baboons: some similarities to premenstrual syndrome (PMS) in women. American Journal of Primatology 9 165-172. (https:// doi.org/10.1002/ajp.1350090302)

Huppertz B 2014 Maternal and fetal factors and placentation: implications for pre-eclampsia. Pregnancy Hypertension 4 244. (https:// doi.org/10.1016/j.preghy.2014.04.015)

Jahan S, Jalali S \& Shami S 2007 Neuroendocrine regulation of prolactin secretion in adult female rhesus monkeys during different phases of the menstrual cycle: role of neuroexcitatory amino acid (NMA). American Journal of Primatology 69 395-406. (https://doi.org/10.1002/ ajp.20357)

Jensen JT, Lefebvre P, Laliberté F, Sarda SP, Law A, Pocoski J \& Duh MS 2012 Cost burden and treatment patterns associated with management of heavy menstrual bleeding. Journal of Women's Health 21 539-547. (https://doi.org/10.1089/jwh.2011.3147)

Johnson WG, Corrigan SA, Lemmon CR, Bergeron KB \& Crusco AH 1994 Energy regulation over the menstrual cycle. Physiology and Behavior 56 523-527.

Kann G \& Denamur R 1974 Possible role of prolactin during the oestrous cycle and gestation in the ewe. Journal of Reproduction and Fertility 39 473-483. (https://doi.org/10.1530/jrf.0.0390473)

Knight D, Robson S \& Scott P 2009 How to treat: menorrhagia. In Australian Doctor, pp 31-36. Sydney, Australia: Australian Doctor.

Lamers WH, Mooren PG, Griep H, Endert E, Degenhart HJ \& Charles R 1986 Hormones in perinatal rat and spiny mouse: relation to altricial and precocial timing of birth. American Journal of Physiology: Endocrinology and Metabolism 251 E78-E85. (https://doi.org/10.1152/ ajpendo.1986.251.1.E78)

Laux-Biehlmann A, d'Hooghe T \& Zollner TM 2015 Menstruation pulls the trigger for inflammation and pain in endometriosis. Trends in Pharmacological Sciences 36 270-276. (https://doi.org/10.1016/j. tips.2015.03.004)

Lehninger AL, Nelson DL \& Cox MM 2008 Lehninger Principles of Biochemistry. New York: Worth Publishers.

Liu Z, Doan QV, Blumenthal P \& Dubois RW 2007 A systematic review evaluating health-related quality of life, work impairment, and health-care costs and utilization in abnormal uterine bleeding. Value in Health 10 183-194. (https://doi. org/10.1111/j.1524-4733.2007.00168.x)

Lynch VJ, Nnamani MC, Kapusta A, Brayer K, Plaza SL, Mazur EC, Emera D, Sheikh SZ, Grützner F \& Bauersachs S 2015 Ancient transposable elements transformed the uterine regulatory landscape and transcriptome during the evolution of mammalian pregnancy. Cell reports $\mathbf{1 0} 551-561$.

McCann TO \& Myers RE 1970 Endometriosis in rhesus monkeys. American Journal of Obstetrics and Gynecology 106 516-523. (https:// doi.org/10.1016/0002-9378(70)90034-7)

McCracken J, Carlson J, Glew M, Goding J, Baird D, Green K \& Samuelsson B 1972 Prostaglandin F2 $\alpha$ identified as a luteolytic hormone in sheep. Nature 238 129-134. (https://doi. org/10.1038/238129a0)

McCracken JA, Custer EE \& Lamsa JC 1999 Luteolysis: a neuroendocrine-mediated event. Physiological Reviews 79 263-323. (https://doi.org/10.1152/physrev.1999.79.2.263)

Medger K, Chimimba CT \& Bennett NC 2010 Seasonal reproduction in the female spiny mouse from South Africa. Journal of Zoology 282 163-170. (https://doi.org/10.1111/j.1469-7998.2010.00726.x)

Merrill JA 1968 Spontaneous endometriosis in the Kenya baboon (Papio doguera). American Journal of Obstetrics and Gynecology 101 569-570. (https://doi.org/10.1016/0002-9378(68)90572-3) 
Modi DN, Godbole G, Suman P \& Gupta SK 2012 Endometrial biology during trophoblast invasion. Frontiers in Bioscience 4 1151-1171.

Monroe S, Atkinson L \& Knobil E 1970 Patterns of circulating luteinizing hormone and their relation to plasma progesterone levels during the menstrual cycle of the rhesus monkey. Endocrinology 87 453-455.

Nelson JF, Felicio LS, Osterburg HH \& Finch CE 1981 Altered profiles of estradiol and progesterone associated with prolonged estrous cycles and persistent vaginal cornification in aging c57bl/6j mice. Biology of Reproduction 24 784-794.

O'Connell BA, Moritz KM, Walker DW \& Dickinson H 2013 Sexually dimorphic placental development throughout gestation in the spiny mouse (Acomys cahirinus). Placenta 34 119-126. (https://doi. org/10.1016/j.placenta.2012.11.009)

O’Neil D 2014 Old world monkeys. In Primates. Behavioral Sciences Department, Palomar College, San Marcos, California, USA

Oduor-Okelo D, Katema R \& Carter AM 2004 Placenta and fetal membranes of the four-toed elephant shrew, Petrodromus tetradactylus. Placenta 25 803-809. (https://doi.org/10.1016/j.placenta.2004.03.001)

Oosterhuis W, Mooren P, Charles R \& Lamers W 1984 Perinatal development of the lung in rat and spiny mouse: its relation to altricial and precocial timing of birth. Neonatology 45 236-243. (https://doi.org/10.1159/000242011)

Peitz B 1981 The oestrous cycle of the spiny mouse (Acomys cahirinus). Journal of Reproduction and Fertility 61 453-459. (https://doi. org/10.1530/jrf.0.0610453)

Quinn TA, Ratnayake U, Dickinson H, Nguyen TH, McIntosh M, Castillo-Melendez M, Conley AJ \& Walker DW 2013 Ontogeny of the adrenal gland in the spiny mouse, with particular reference to production of the steroids cortisol and dehydroepiandrosterone. Endocrinology 154 1190-1201. (https://doi.org/10.1210/en.20121953)

Rasweiler JJ 1991 Spontaneous decidual reactions and menstruation in the black mastiff bat, Molossus ater. American Journal of Anatomy 191 1-22. (https://doi.org/10.1002/aja.1001910102)

Rasweiler JJ \& De Bonilla H 1992 Menstruation in short-tailed fruit bats (Carollia spp.). Journal of Reproduction and Fertility 95 231-248. (https://doi.org/10.1530/jrf.0.0950231)

Reid RL 1991 Premenstrual syndrome. New England Journal of Medicine 324 1208-1210. (https://doi.org/10.1056/NEJM199104253241710)

Renfree MB 2012 Why menstruate? BioEssays 34 1. (https://doi. org/10.1002/bies.201190071)

Robson A, Harris LK, Innes BA, Lash GE, Aljunaidy MM, Aplin JD, Baker PN, Robson SC \& Bulmer JN 2012 Uterine natural killer cells initiate spiral artery remodeling in human pregnancy. FASEB Journal 26 4876-4885. (https://doi.org/10.1096/fj.12-210310)

Rothchild I 1981 The regulation of the mammalian corpus luteum. In Proceedings of the 1980 Laurentian Hormone Conference, pp 183-298. Boston: Academic Press.

Rothchild I 2013 The regulation of the mammalian corpus luteum. In Recent Progress in Hormone Research: Proceedings of the 1980 Laurentian Hormone Conference, p 183. Academic Press.

Rudolph M, Docke WD, Muller A, Menning A, Rose L, Zollner TM \& Gashaw I 2012 Induction of overt menstruation in intact mice. PLoS ONE 7 e32922. (https://doi.org/10.1371/journal.pone.0032922)

Salamonsen LA 2003 Tissue injury and repair in the female human reproductive tract. Reproduction 125 301-311. (https://doi. org/10.1530/rep.0.1250301)

Salker M, Teklenburg G, Molokhia M, Lavery S, Trew G, Aojanepong T, Mardon HJ, Lokugamage AU, Rai R, Landles C, et al. 2010 Natural selection of human embryos: impaired decidualization of endometrium disables embryo-maternal interactions and causes recurrent pregnancy loss. PLOS ONE 5 e10287. (https://doi. org/10.1371/journal.pone.0010287)

Sampson JA 1927 Metastatic or embolic endometriosis, due to the menstrual dissemination of endometrial tissue into the venous circulation. American Journal of Pathology 393.
Schams D, Schallenberger E, Hoffmann B \& Karg H 1977 The oestrous cycle of the cow: hormonal parameters and time relationships concerning oestrus, ovulation, and electrical resistance of the vaginal mucus. Acta Endocrinologica 86 180-192.

Seif MW, Diamond K \& Nickkho-Amiry M 2015 Obesity and menstrual disorders. Best Practice and Research Clinical Obstetrics and Gynaecology 29 516-527. (https://doi.org/10.1016/j.bpobgyn.2014.10.010)

Seifert AW, Kiama SG, Seifert MG, Goheen JR, Palmer TM \& Maden M 2012 Skin shedding and tissue regeneration in African spiny mice (Acomys). Nature 489 561-565. (https://doi.org/10.1038/nature11499)

Sherman BM \& Korenman SG 1975 Hormonal characteristics of the human menstrual cycle throughout reproductive life. Journal of Clinical Investigation 55 699-706.

Sinha Y, Salocks C \& Vanderlaan W 1975 Prolactin and growth hormone levels in different inbred strains of mice: patterns in association with estrous cycle, time of day, and perphenazine stimulation. Endocrinology 97 1112-1122. (https://doi.org/10.1210/endo-97-5-1112)

Smith SD, Dunk CE, Aplin JD, Harris LK \& Jones RL 2009 Evidence for immune cell involvement in decidual spiral arteriole remodeling in early human pregnancy. American Journal of Pathology $\mathbf{1 7 4}$ 1959-1971. (https://doi.org/10.2353/ajpath.2009.080995)

Strasser H 1968 A breeding program for spontaneously diabetic experimental animals: Psammomys obesus (sand rat) and Acomys cahirinus (spiny mouse). Laboratory Animal Care 18328.

Strassmann BI 1996 The evolution of endometrial cycles and menstruation. Quarterly Review of Biology 71 181-220. (https://doi. org/10.1086/419369)

Struman I, Bentzien F, Lee H, Mainfroid V, D'Angelo G, Goffin V, Weiner RI \& Martial JA 1999 Opposing actions of intact and N-terminal fragments of the human prolactin/growth hormone family members on angiogenesis: an efficient mechanism for the regulation of angiogenesis. PNAS 96 1246-1251. (https://doi.org/10.1073/pnas.96.4.1246)

Su J-H, Aso T, Motohashi T, Aochi H, Matsuoka M, HORIE K \& NISHIMURA T 1980 Radioimmunoassay method for baboon plasma gonadotropins. Endocrinologia japonica 27 513-520.

Teklenburg G, Salker M, Molokhia M, Lavery S, Trew G, Aojanepong T, Mardon HJ, Lokugamage AU, Rai R, Landles C, et al. 2010 Natural selection of human embryos: decidualizing endometrial stromal cells serve as sensors of embryo quality upon implantation. PLOS ONE 5 e10258. (https://doi.org/10.1371/journal.pone.0010258)

The International Union for Conservation of Nature and Natural Resources 2015 The IUCN Red List of Threatened Species. The International Union for Conservation of Nature and Natural Resources: Gland, Switzerland.

Thorburn G, Bassett J \& Smith I 1969 Progesterone concentration in the peripheral plasma of sheep during the oestrous cycle. Journal of Endocrinology 45 459-469.

Treloar SA, Bell TA, Nagle CM, Purdie DM \& Green AC 2010 Early menstrual characteristics associated with subsequent diagnosis of endometriosis. American Journal of Obstetrics and Gynecology 202534. e531-534.e536. (https://doi.org/10.1016/j.ajog.2009.10.857)

Van der Horst C 1949 The placentation of Elephantulus. Transactions of the Royal Society of South Africa 32 435-629. (https://doi. org/10.1080/00359194909519872)

Van der Horst C \& Gillman J 1941 The menstrual cycle in Elephantulus. South African Journal of Medical Sciences 6 27-42.

Van Huis A, Van Itterbeeck J, Klunder H, Mertens E, Halloran A, Muir G \& Vantomme P 2013 Edible Insects: Future Prospects for Food and Feed Security. Food and Agriculture Organization of the United Nations (FAO) accessible at http://www.fao.org/docrep/018/i3253e/i3253e.pdf van Weerden WM, Bierings HG, Van Steenbrugge GJ, De Jong FH \& Schröder FH 1992 Adrenal glands of mouse and rat do not synthesize androgens. Life Sciences 50 857-861. (https://doi. org/10.1016/0024-3205(92)90204-3)

Wang Q, Xu X, He B, Li Y, Chen X \& Wang J 2013 A critical period of progesterone withdrawal precedes endometrial breakdown and 
shedding in mouse menstrual-like model. Human Reproduction 28 1670-1678. (https://doi.org/10.1093/humrep/det052)

Wasser SK \& Barash DP 1983 Reproductive suppression among female mammals: implications for biomedicine and sexual selection theory. Quarterly Review of Biology 58 513-538. (https://doi. org/10.1086/413545)

Wei S, Schmidt MD, Dwyer T, Norman RJ \& Venn AJ 2009 Obesity and menstrual irregularity: associations with SHBG, testosterone, and insulin. Obesity 17 1070-1076. (https://doi.org/10.1038/oby.2008.641)

Witherspoon D 1971 The oestrous cycle of the mare. Equine Veterinary journal 3 114-117. (https://doi.org/10.1111/j.2042-3306.1971. tb04451.x)
Wube T, Haim A \& Fares F 2008 Reproductive response of xeric and mesic populations of the spiny mouse Acomys to photoperiod acclimation. Journal of Arid Environments 72 440-447. (https://doi org/10.1016/j.jaridenv.2007.06.014)

Wurtman JJ, Brzezinski A, Wurtman RJ \& Laferrere B 1989 Effect of nutrient intake on premenstrual depression. American Journal of Obstetrics and Gynecology 161 1228-1234. (https://doi. org/10.1016/0002-9378(89)90671-6)

Zhang X, Zhu C, Lin H, Yang Q, Ou Q, Li Y, Chen Z, Racey P, Zhang S \& Wang H 2007 Wild fulvous fruit bats (Rousettus leschenaulti) exhibit human-like menstrual cycle. Biology of Reproduction 77 358-364. (https://doi.org/10.1095/biolreprod.106.058958)

Received in final form 6 March 2018

Accepted 11 April 2018 http://jme.endocrinology-journals.org https://doi.org/10.1530/JME-17-0278
(C) 2018 Society for Endocrinology Published by Bioscientifica Ltd. Printed in Great Britain 